\title{
Study of Modern Educators
}

\author{
He Lirong, Sun Keli \\ Tianjin University
}

\begin{abstract}
With the development of modern society, the state and society have proposed new requirements for educators. Besides teaching, modern educators also need to integrate themselves into the lives of students. By combining teachers' basic literacy with science and technology, educational methods can be diversified. In this way, educators will positively influence the formation and development of students' qualities, thus achieving the objective of modern education. The paper analyzes the function transformation of educators, sums up the basic qualities required for modern educators and the development challenges faced by them, focuses on finding solutions, and provides references for the future development of modern educators.
\end{abstract}

Keywords-Modern educators; Function transformation; Basic quality requirements; Development

\section{INTRODUCTION}

\section{A. The formation of modern educators}

With the development of modern society, all walks of life have shown new structural characteristics, which reflect in the increase of the types of industries, the diversification of channels to acquire information, the fragmentation of knowledge structure, and the rapidity of communications and transportation. As the Internet occupies more parts in people's lives, it has affected the educator career development. In addition, the state and society have proposed new requirements for educators. Educators, a kind of people no longer just

"proselytizing instructs and dispelling doubt", have been given a new role in this era-modern educators.

\section{B. Educators}

Educators are those who directly influence knowledge seekers, including school teachers, the designers of education plans and textbooks, education administrators, and others involved in educational activities.

\section{Modern Educators}

Adapting to various factors such as the development of modern society, social system, politic and culture, modern educators exert an influence on the formation and development of the qualities of knowledge seekers (students as the main body), and enables them to reach the purpose of education.

\section{The significance of studying modern educators}

The meaning of the study of modern educators lies in the fact that only by thoroughly understanding the social needs and professional demands of modern educators and exploring the limitations of their development can we better find out the problems encountered by them in the development process. The society and people will pay more attention to the development of modern educators, thereby helping us to seek solutions and improving the development system of modern educators so as to make a due responsibility for the development of education in China.

Liang Qichao, a famous politician and educator in early China, said, "From disappeared to reappeared, from abolished to readopted, from weak to strong, all those changes are based on school education". Therefore, modern educators largely refer to teachers in education.

\section{FUNCTION TRANSFORMATION OF MODERN EDUCATORS}

\section{A. The transformation from "Confucian classics teachers" to "Human teachers"}

The so-called "Confucian classics teachers" means that the teachers' primary task is "preaching", followed by "teaching", and the third is "dispelling confusion." Teachers only pay attention to students' mastery of knowledge and development of learning skills. Throughout the ages, teachers have been likened to "hardworking gardeners" and "engineers of the human soul." But today, the gardener's job is to prune flowers and grass almost exactly according to someone's will and aesthetic concept, creating a uniform posture and man-made artificial beauty. At the same time, the natural personality and free individual development of students have been seriously repressed and distorted [1].

A pedagogy expert said in Chinese Autocratic Education: "In today's classrooms in China, students are sitting, and teachers are standing. But the situation is reversed in their spirit Though the teacher is standing, the body of the sitting student hides a trembling and standing soul, even a groaning soul."[2]

The so-called "Human teachers" are proposed relatively to "Confucian classics teachers", that is, teachers not only pay attention to the students' mastery of knowledge and skills, but also personality cultivation in the teaching process. Such students will be self-respecting, self-reliant, self-improved and self-disciplined, forming a clear understanding of the value of their own lives [2]. It is also compatible with the concept of moral education proposed by some educators. In the process of teaching, besides the visualized teaching achievements including test scores, modern educators will also focus on cultivating students' morality, thoughts, values, and even social outlooks. With the universalization of Internet, the world has 
gradually become a global village that blends in with each other. The traditional model of result-oriented education in China has gradually exposed its drawbacks in the current era, that is, without creative-thinking and exploratory spirit, students just sit in the classroom and repeat the basic knowledge that teachers given, let alone think about problems. However, it is not to criticize the current exam-oriented education in China. We cannot deny that examination is still the most direct and fair way to select talents and average educational resources.

Here is an interesting example of comparing educational methods in China and those in Western countries via "painting an apple in the class".

In the Chinese classroom, the teacher directly tells the students that, at first, draw a square on the white paper, and then remove the four angles to make it an octagon, that is close to a circle. To draw a fruit, it should be a square, not a circle. Finally, the teacher let the students follow the finished picture on the blackboard to draw their own apple. Although the teaching results are effective in this way, students does not sum up their own experience from the nature of an apple (object or knowledge) in the process of education so that they just copy the teacher's painting into their own brains without thinking. Therefore, the ability of Chinese students to form personal knowledge system is relatively weak.

In contrast, painting an apple in the classroom in a western country is not as "efficient" as that in China. At the beginning, the teacher just introduces the cleaned apples and distributes them to students, giving them a lot of autonomous options. "You can take a look at it, smell it, touch it, play it..., besides, these apples are clean so you can eat it if you like." After a while, many students have already eaten their apples. At this time, the teacher begins to assign the task: "We need to draw an apple for this lesson. Now everyone needs to draw an apple on your notebook." Since most of the students have already eaten their apple, what they draw for the first time may look like a pumpkin. It may look like a pear for the second time. Until the third time, it looked a bit like an apple [3]. But during such a slow teaching process, the students established their own independent understanding of an apple (object or knowledge). An apple is either sweet or sour, crisp or soft, and some people like it, while others don't. The students can add their own impression of apple in the next drawing exercise, thus deepening their understanding and mastery of apple (knowledge), and eventually forming their own knowledge system and structure.

\section{B. The Transformation From the duplicator of textbooks to the stimulator of student learning}

Teacher is no longer the sole source of knowledge for students. The rapid development of modern science and technology provides students with more channels to get knowledge and information. Teachers should not only impart knowledge from textbooks, but also instruct students to acquire skills and methods to process various information and knowledge [1].

Textbooks have always been at the dominance in China's education. Textbooks embody the common standards of education, and also provide educators with the basic content of the knowledge system. However, the content of textbooks is not comprehensive for the construction of students' knowledge system. The premise that modern educators guide students to acquire knowledge through multiple channels is that educators themselves need to be proficient in the use of various modern technologies and can adapt to the development trend of society by keeping pace with the times, constantly updating knowledge system and social cognition, and improving personal qualities. Teachers should not to be rigid textbook movers.

Modern educators are required to be able to use their own educational experience, combining the individual development of students, guide students to learn to use different social media and obtain different levels of knowledge in various fields relying on the development of modern information technology. Educators need to cultivate the autonomy and independence of students in learning, thereby developing the characteristics (autonomy and independence) into students' lives and gradually improving the students' identity construction.

\section{The transformation from "teachers" to "mediators"}

Ideal teachers should understand how people of different ages and people at different development stages perceive the world around them, and how cultural and social differences, constantly changing individuals and their own obstacles affect these perceptions. These teachers should also understand how ideas are constructed and how critical abilities are used and developed; they can identify specific sources of knowledge and know the way to use the available communication media to find sources of knowledge when needed [1].

Modern educators participate in educational activities more often as guides. Teaching is important, but the traditional model of classroom teaching is changing in the process of modern development. Teachers need more empathy in teaching, learning and daily life, and fully understand and respect the behaviors of students. Instead of blindly resisting the spread of new culture, modern educators need to discover the positive information of the social mainstream in the trend culture, encouraging and correctly guiding students to benefit from accepting new culture and new ideas while allowing students to subtly improve their knowledge system of social life and develop into a social person with sound physical and mental integrity. 


\section{The transformation from cultural communicators to $R \& D$ teachers}

Here we need to explain the concept of R\&D teachers. $\mathrm{R} \& \mathrm{D}$ refers to Research and Development. $\mathrm{R} \& \mathrm{D}$ teacher is the abbreviation of research and development teacher [1].

Modern educators not only remain at the level of knowledge dissemination. Teaching is only one part of the functions of educators. At present, our society also requires modern educators to constantly improve themselves and seek self-identification from teaching activities so that they are not only educators for students but also for themselves. Modern educators need to jump out of the locked-in circle of their own work, comprehensively understand and analyze their own personal development, and unify their career plan and life plan.

\section{The BASIC QuAlities That MOdERn EducATORS SHOUld HAVE}

- Basic teaching skills; mastery of professional knowledge and good teaching skills

- Modern educators should have excellent moral character. Mr. Sun Yat-sen mentions that the psychological orientation of the people is the key to the success of the country, so it is of great significance to strengthen the psychological construction for the people in the Republic of China, especially for the revolutionaries.

- The heart of love, which is the sum of the teacher's psychology, beliefs, interests, temperament, ability, will, emotion, character, and other psychological characteristics

- Modern educators should keep pace with the times and master basic scientific skills as the development of modern society. Just as President Xi Jinping has said, "To give students a bowl of water, teachers should have a pool of water". Education is a process of passing on knowledge, where the teacher's own quality will be gradually taught to the students. Durkheim believes that education is an authority in essence. The authoritativeness of an educator manifests itself in two aspects in their relationship with children affected by him. Firstly, children are naturally in a passive state; secondly, because that teachers are superior in experience and self-cultivation, naturally they will have an advantage for students and will provide their desired efforts to make an influence. [4] Therefore, this requires modern educators to keep up with the times, constantly update their knowledge base, surpass themselves, and become creative, thus stimulating students to take the initiative to receive education.

- Modern educators should have the spirit of initiative and innovation, and find solutions in the constant changing and difficult situation, instead of waiting for educational reforms.

- Modern educators should change their position to establish equal coexistence status with the educated. Sternhaus, a famous English curriculum theorist, once puts forward the view that changing from "the authority role" to "the neutral role" for modern moral educators is an important task.

\section{THE DEVELOPMENT PROBLEMS AND CORRESPONDING SOLUTIONS OF MODERN EDUCATORS}

\section{A. Competitive teaching for enrolment rate or quality teaching for students}

Mencius clearly states, "Benevolence, righteousness and wisdom are not from external world. I was born with them [5]." It is said that although people are born with good traits, they are easily affected by the external environment and temperament, easy to lose their heart. Therefore, our modern educators are easily trapped in the teaching process. They are trapped in a choice dilemma, either teaching to get a higher enrolment rate or concerning more about students' self-quality and guiding students to study independently. The second choice, however, has no way to get the quantitative control of the enrollment rate [6].

So how do we solve this problem? The author believes that in modern teaching, modern educators should focus on understanding educational receptors, that is, the students' own situation, and fully understand the indicators of modern education. Integrate traditional teaching and moral education so that students will not only have a good result in the hard assessment of scores, but also get improvement in personal qualities.

\section{B. Stubborn teaching schemes and plans}

Most of the educators are extremely easy to limit themselves to their own small circles, repeating the past experiences, and using the same teaching method in the face of different audiences.

Dirk Stowe, a famous German educator, points out in his book- Guideline for the Development of German Teachers that teachers must enable others to pursue truth, goodness, and beauty and maximize their talents and intelligence [7]

To achieve this lofty goal, teachers must constantly improve their self-cultivation in teaching. Facing diversification of educational situations, modern educators are required to fully understand the situation of students and melt into their lives, not only as an educator but also as a companion with rich life experience and social practice. By understanding the personal condition and differences of students based on teaching objectives, modern educators should give full play of the subjective initiative, set an example, use their intellectual charisma and personality literacy to promote students, and actively communicate with students. To think about the problems encountered in the teaching process in student's stand, educators should creatively explore flexible teaching methods that varies from person to person. 


\section{The decentralized impact of modern science and technology on teaching}

For example, students indulge in their mobile phones in and after class. Mobile phone, a token of this modern age, has fully penetrated into our lives: it brings new words one after another, such as "Phubbing"; even newly-born children can play puzzle games on the tablet. Students, as the main audience in modern education, have also been affected by the smart phone revolution. The phenomenon that everyone has a phone is ubiquitous in campus. On one hand, mobile phones bring us information retrieval convenience; on the one other hand, some negative effects also originate in mobile phones. Students are distracted in class and play mobile phones under the table. Even if mobile phones are prohibited in class, many students are always thinking about playing computer or mobile phone after class or leaving school.

Correspondingly, some schools have made countermeasures. For example, mobile phones are not allowed in schools. Once someone's phone is found in school, it will be immediately taken away. The owner will be given demerits, and his parents will be informed. The semi-enclosed model of running schools requires that all students need to study and live on campus. Students' time schedule of study and rest is strictly controlled; the head teacher irregularly patrols the students' learning activities during class and uses deterrence of penalty to prevent students from playing phones. These measures have indeed played a role to a certain extent, and students follow the learning rules and regulations passively. However, the learning initiative will be greatly reduced, and it will also cause serious rigid relationship between teachers and students.

Modern educators should actively make full use of modern technology, make hard thing simple, carry out innovations in teaching methods, and fully integrate modern science and technology into teaching. To incorporate modern technologies in the teaching process, such as making presentation via animation teaching, making videos, establishing an online teaching interactive platform, and enriching the content of knowledge, modern educators can attract the attention of students, stimulate their interests, transfer the passive condition into an advantage, and transform the passive learning into active and self-directed learning. Modern educators should learn to apply new technology-based teaching methods to further guide students to rationally use modern technology. Students will find education pleasure while being educated.

\section{CONCLUSION}

Therefore, the development problems faced by modern educators and the corresponding solutions are not separated, but rather blended. Whether stick to obsolete teaching methods or utilitarian teaching, or resolve conflicts between modern technology and teaching, modern educators are urgently required to be creative, adhere to lifelong learning, constantly expand their knowledge systems, and improve their relationship with students.

\section{REFERENCES}

[1] Nanrui. The trend of the transformation of modern teachers' functions. (School of Education, Bohai University, Jinzhou, Liaoning, 1210oo)

[2] Li Ning. The changing trend of the role of contemporary teachers [J]. (Education Science, 2001(2))

[3] Wang Nan. Seeing the Differences in Curriculum Culture between Chinese, Japanese, and American Teachers in Painting Apples (Mianyang Teachers College, 621000)

[4] Durkheim [France]. Moral Education [M]. Shanghai People's Publishing House, 2[x] 1.322, 32 I, 324.

[5] Peng Zhengmei. Taoism, teaching and imitation, the forgotten Confucian tradition in the professional development of modern teachers. (2013,12 (Total 317))

[6] Yu Yu. Education based, to be a qualified modern educator. (Hongzhi Middle School, Beijing 100013)

[7] Li Xuenong. On Teacher Educators. (Faculty of Education, Nanjing Normal University, Nanjing, Jiangsu 210097, China)

[8] Guo Xiaowei, Ai Wei. Pioneer of modern educational psychology in China. (Landai World 2014, early April)

[9] Xiao Fengxiang, Xiao Yanting. Quality Requirements and Responsibilities of Modern Vocational Education Educators. (2012,9(20),No. 27) 